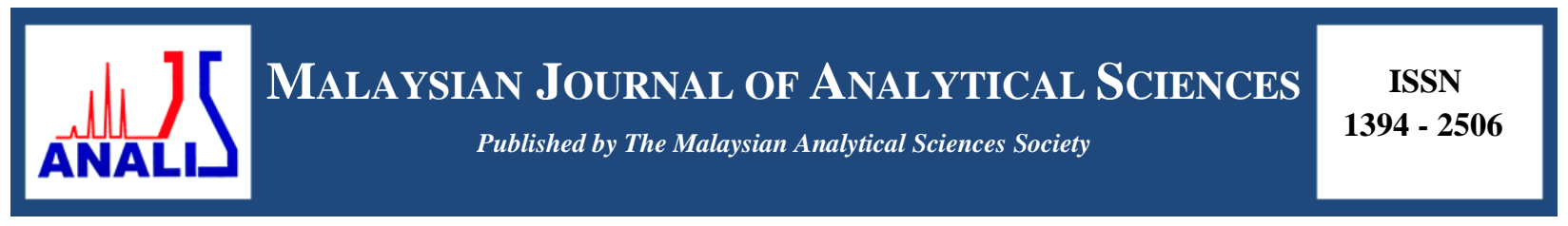

\title{
LIQUID NATURAL RUBBER TOUGHENED POLY(LACTIC ACID) BLEND: EFFECTS OF COMPATIBILIZER TYPES AND LOADINGS ON THERMO-MECHANICAL PROPERTIES
}

\author{
(Adunan Asid Polilaktik Diperkuat Getah Asli Cecair: Kesan Jenis dan Kandungan Penserasi \\ Terhadap Sifat Terma-Mekanik)
}

\author{
Mohd Farid Hakim Mohd Ruf, Sahrim Ahmad, Ruey Shan Chen*, Dalila Shahdan, Farrah Diyana Zailan \\ School of Applied Physics, \\ Faculty of Science and Technology, \\ Universiti Kebangsaan Malaysia, 43600 UKM Bangi, Selangor, Malaysia \\ *Corresponding author: chen@ukm.edu.my
}

Received: 20 July 2017; Accepted: 28 April 2018

\begin{abstract}
This research was carried out to investigate the addition of grafted copolymers of maleic anhydride grafted-polylactic acid (PLAg-MA) and maleic anhydride grafted-natural rubber (NR-g-MA) on the mechanical and thermal properties of polylactic acid/ liquid natural rubber (PLA/LNR) blends. Prior to blend preparation, the PLA-g-MA and NR-g-MA were the first selfsynthesized by mixing maleic anhydride (MA) and dicumyl peroxide (DCP) which acted as initiator with the PLA and natural rubber (NR), respectively. The PLA/LNR, PLA/LNR/PLA-g-MA and PLA/LNR/NR-g-MA blends were prepared via meltblending method. The loading of PLA-g-MA and NR-g-MA was varied between 5, 10 and 15\%, respectively. By comparing to the control sample (neat PLA/LNR blend), the addition of PLA-g-MA with 5 and $10 \%$ led to increment in tensile strength up to $22 \mathrm{MPa}$, whereas NR-g-MA promoted a negative trend of tensile properties to the blends. Differential scanning calorimetry (DSC) and thermogravimetry analysis (TGA) results showed the enhanced thermal stability for PLA/LNR/PLA-g-MA blend. Fourier transform infrared (FTIR) analysis confirmed the chemical interaction between the PLA and NR components where the grafted copolymers were successfully grafted onto PLA backbone and bonded with NR.
\end{abstract}

Keywords: polymer blend, polylactic acid, toughening agent, compatibilizer, thermal

\begin{abstract}
Abstrak
Kajian ini dijalankan bagi mengkaji kesan penambahan kopolimer maleik anhidrida cantuman-asid polilaktik (PLA-g-MA) dan maleik anhidrida cantuman-getah asli (NR-g-MA) terhadap sifat mekanik and terma polimer adunan asid polilaktik/cecair getah asli (PLA/CGA). Sebelum penyediaan adunan, PLA-g-MA dan NR-g-MA terlebih dahulu disintesiskan dengan mengadun maleik anhidrida (MA) dan dikumil peroksida (DCP) yang bertindak sebagai pemula bersama dengan PLA dan getah asli (GA). Adunan PLA/LNR, PLA/LNR/PLA-g-MA dan PLA/LNR/NR-g-MA disediakan dengan menggunakan kaedah pengadunan dalaman. Kandungan PLA-g-MA dan NR-g-MA masing-masing divariasikan kepada 5, 10 dan 15\%. Berbanding dengan sampel kawalan (adunan PLA/LNR), penambahan PLA-g-MA sebanyak 5 dan $10 \%$ memberikan peningkatan terhadap kekuatan tegangan sehingga $22 \mathrm{MPa}$ manakala NR-g-MA memberikan corak penurunan terhadap adunan. Keputusan kalorimeter pemgimbasan pembezaan (DSC) dan analisa termogravimetri (TGA) menunjukkan peningkatan kestabilan terma adunan PLA/LNR/PLA-g-MA. Analisa spektroskopi inframerah transformasi Fourier (FTIR) membuktikan interaksi kimia berlaku antara komponen PLA dan NR di mana kopolimer cantuman berjaya dicantum pada tulang belakang PLA dan diikat dengan NR.
\end{abstract}

Kata kunci: polimer adunan, asid polilaktik, agen penguat, penserasi, terma 


\title{
Mohd Farid Hakim et al: LIQUID NATURAL RUBBER TOUGHENED POLY(LACTIC ACID) BLEND: EFFECTS OF COMPATIBILIZER TYPES AND LOADINGS ON THERMO- MECHANICAL PROPERTIES
}

\begin{abstract}
Introduction
Polymer blending is well known as an effective method for improving nature physical properties of one or both individual components. Unfortunately, polymer blends are mostly not miscible. To solve this immiscibility issue, the utilization of coupling agent or compatibilizer is required to improve the interfacial adhesion between the inherently immiscible polymeric components, which subsequently increasing the mechanical and other properties of blends. For instance, previous study reported that the incorporation of ethylene-glycidyl methacrylate (E-GMA) as compatibilizer had improved the compatibility of the recycled high-density polyethylene/polyethylene terephthalate (HDPE/PET) blend which subsequently resulted in the increase of mechanical properties [1]. The improvement of polymer blending properties can be achieved by the addition of toughening agent like co-polymer block and liquid natural rubber (LNR) [2]. LNR has been synthesized via a photodegradation method by cutting natural rubber (NR) into small cubes prior to mixing in the solution containing toluene solvent, methylene blue, rose Bengal and methanol. LNR was formed after the exposure under ultraviolet for approximately 12-20 days [3]. The addition of LNR has successfully increased the mechanical properties such as tensile and impact strength in polymer blends and composites $[2,3]$.
\end{abstract}

In order to obtain better adhesion between the blending components, some modification are required [4]. One of the cheapest and simplest methods is by using the self-synthesized compatibilizer. The synthesis of compatibilizer usually involves a free radical grafting polymerization in which the monomers are often grafted onto polar polymer backbones. Maleic anhydride (MA) was selected as the main functional group for compatibilizing/coupling agent and the maleic copolymers have been extensively used for grafting onto the binary immiscible polymer blends in the previous research works [5, 6]. By adding the MA, the properties and interfacial adhesion of the blends were enhanced [7]. As reported by Orozco and his coworkers, the blending of PLA grafted with starch led to the better interaction as compared to the blend without the addition of MA as compatibilizer [5]. Besides, the incorporation of NR-g-MA promoted compatibilization for various blends and composites such as natural rubber/short nylon fiber composites and acrylonitrile-butadiene copolymer (NBR) [8, 9], thereby has resulted in the increase of modulus and tensile strength. Rui and his coworkers also reported that the incorporation of grafted MA compatibilizer gave better tensile property and improved interfacial adhesion of PLA/soy protein concentrate (SPC) composites [10].

Numerous published research works have been reported on the use of PLA or PLA/LNR as the matrix in the composites, such as PLA/PP blends [11], PLA/LNR/NiZn ferrite [12], and etc. Nevertheless, the shortcomings of these matrices should be highlighted which are the brittleness of PLA but the toughening effect on PLA can be imparted by LNR (PLA/LNR). However, the PLA/LNR somehow showed the incompatibility problem which thereby restricting the properties. In this aspect, the modification of PLA/LNR matrix is required. The aim of this research was to investigate the effect of adding different types of self-synthesized compatibilizers (PLA-g-MA or NR-g-MA) into the PLA/LNR blends and the compatibilizer loadings on the mechanical, thermal and chemical properties of the blends.

\section{Materials}

Materials and Methods

Polylactic acid (PLA) was purchased from Nature Works LLC, UNIC Technology (SUZHOU) LTD with average molecular weight $5.5 \times 10^{4} \mathrm{~g} / \mathrm{mol}$, relative viscosity of 2.5 , melt flow index of $35 \mathrm{~g} / 10 \mathrm{~min}$ and melting point of 160 $170{ }^{\circ} \mathrm{C}$. SMR-L grade natural rubber (NR) with molecular weight $2.5 \times 10^{6} \mathrm{~g} / \mathrm{mol}$ was obtained from Malaysian Rubber Board (MRB). Maleic Anhydride (MA) with 99\% purity, molecular weight of $98.06 \mathrm{~g} / \mathrm{mol}$ and dicumyl peroxide (DCP) were purchased from Aldrich Chemistry company.

\section{Preparation of liquid natural rubber}

The liquid natural rubber (LNR) was synthesized using photochemical degradation or an oxidation technique of NR [13]. About $1.5 \mathrm{~kg}$ of NR were cut into small pieces and soaked in $60 \mathrm{~cm}^{3}$ glass flask that filled with approximately $4000 \mathrm{ml}$ of toluene for 24 hours. After that, $0.3 \mathrm{~g}$ of methylene blue, $0.39 \mathrm{~g}$ of rose Bengal and $15 \mathrm{ml}$ of methanol were added to the mixture. The mixture was stirred continuously by a mechanical stirrer at $10 \mathrm{rpm}$ under the exposure to visible light for 10 days. 


\section{Preparation of maleic anhydride grafted - polylactic acid and - natural rubber}

Before use, PLA pellets were dried for 24 hours at $60{ }^{\circ} \mathrm{C}$ in an oven to eliminate the moisture. The DCP was used asan initiator. The composition of MA and DCP was fixed at 3.6 and $9 \mathrm{phr}$, respectively $[4,14]$. The grafting of MA onto PLA was carried out by using the internal mixer. Firstly, PLA pellets were fed into internal mixer until it was fully melted before adding DCP. For the next $3 \mathrm{~min}$, MA was added and left for $15 \mathrm{~min}$. The temperature of internal mixer was set at $190{ }^{\circ} \mathrm{C}$ and the screw speed was set at $80 \mathrm{rpm}$. The obtained grafted copolymers were then cut into small pieces to be used in the blending with PLA and LNR.

\section{Blending preparation}

In the presence and absence of compatibilizer, PLA/LNR blends were prepared using an internal mixer (Haake Rheomix 600P) with a processing mixing temperature at $190^{\circ} \mathrm{C}$, a rotor speed of $80 \mathrm{rpm}$ and mixing time of 15 min. The PLA/LNR was fixed at the ratio of 90:10 (wt:wt), whereas PLA-g-MA and NR-g-MA were added at 5, 10 and $15 \%$, respectively. PLA was first placed into the mixer and allowed to melt for about 4 minutes, followed by the introduction of LNR which took another 3 minutes. Finally, the grafted copolymers were added into the mixing and it was completed in 15 minutes. After blending process, the samples were prepared via compression moulding using a hot press machine (LABTECH Engineering Company LTD) under pressure $6.9 \mathrm{MPa}$ at $190{ }^{\circ} \mathrm{C}$. A $3 \mathrm{~mm}$ dumb bell shape mould was used for moulding process. The periods for compression moulding were set as 4 minutes for pre-heating and venting process, 5 minutes for full pressing and 3 minutes for cool pressing.

\section{Characterization}

The tensile test of the samples was conducted using tensile machine (model Testometric M500-50CT) with $10 \mathrm{kN}$ load cell at a crosshead speed of $5 \mathrm{~mm} / \mathrm{min}$ according the standard ASTM D638-03. At least five samples were tested for each composition. The thermal tests were carried out using Thermogravimetric Analyzer (model Shimadzu DSC-60 Plus Series) and Differential Scanning Calorimetry (model Shimadzu DTG-60). A chemical analysis was conducted by using FTIR-Near infrared instrument (model Perkin Elmer Spectrum 400 FT-IR). The samples were scanned from 650 to $4000 \mathrm{~cm}^{-1}$.

\section{Tensile properties}

\section{Results and Discussion}

Figure 1 shows the effect of PLA-g-MA loading on the (a) tensile strength and (b) Youngs modulus of the blends. By adding 5\% of PLA-g-MA, it showed a slight increment in tensile strength, which increased about $2 \%$. The optimum tensile strength was achieved at 10\% PLA-g-MA ( 22 MPa), which increased by approximately $15 \%$. The great improvement in the blend properties suggests that the presence of PLA-g-MA has promoted a better compatibility and stronger adhesion between the PLA and LNR components and thus promoting a more homogeneous blend. As the loading of PLA-g-MA increased up to $15 \%$, the tensile strength showed a significant reduction. The reduction in tensile properties was due to the less uniform and weak adhesion of the components in the blends. For NR-g-MA, the tensile strength showed a gradual reduction upon the increase of NR-g-MA loading from 5 to $15 \%$. The reduction could be due to rubbery nature of NR [15].

On the other hand, the presence of PLA-g-MA resulted in a lower Young's modulus value, which decreased about $12 \%$ than that of PLA/LNR blend (Figure 1(b)). This reduction in Young's modulus was expected and the similar trends have been reported in the previous studies $[1,16]$. For both compatibilizers at the loadings of 10 and $15 \%$, the Young's Modulus of both blends was found to be constant as the compatibilizer achieved the optimum loading at $10 \%$. Therefore, it was believed that the ability to withstand the tension has achieved the same level since the compatibilizer was saturated along the interface area in the blends at $15 \%$.

For the elongation at break shown in Figure 1(c), the addition of compatibilizer did not provide positive effect on PLA/LNR blends, as observed by the lower values than that of PLA/LNR, irrespective to the compatibilizer types. The reduction in elongation at break implies the increased brittleness of the blends. By comparing the effectiveness of PLA-g-MA and NR-g-MA, the earlier compatibilizer with 10\% (optimum loading) was shown to be more suitable than the latter one. 


\section{Mohd Farid Hakim et al: LIQUID NATURAL RUBBER TOUGHENED POLY(LACTIC ACID) BLEND: EFFECTS OF COMPATIBILIZER TYPES AND LOADINGS ON THERMO- MECHANICAL PROPERTIES}
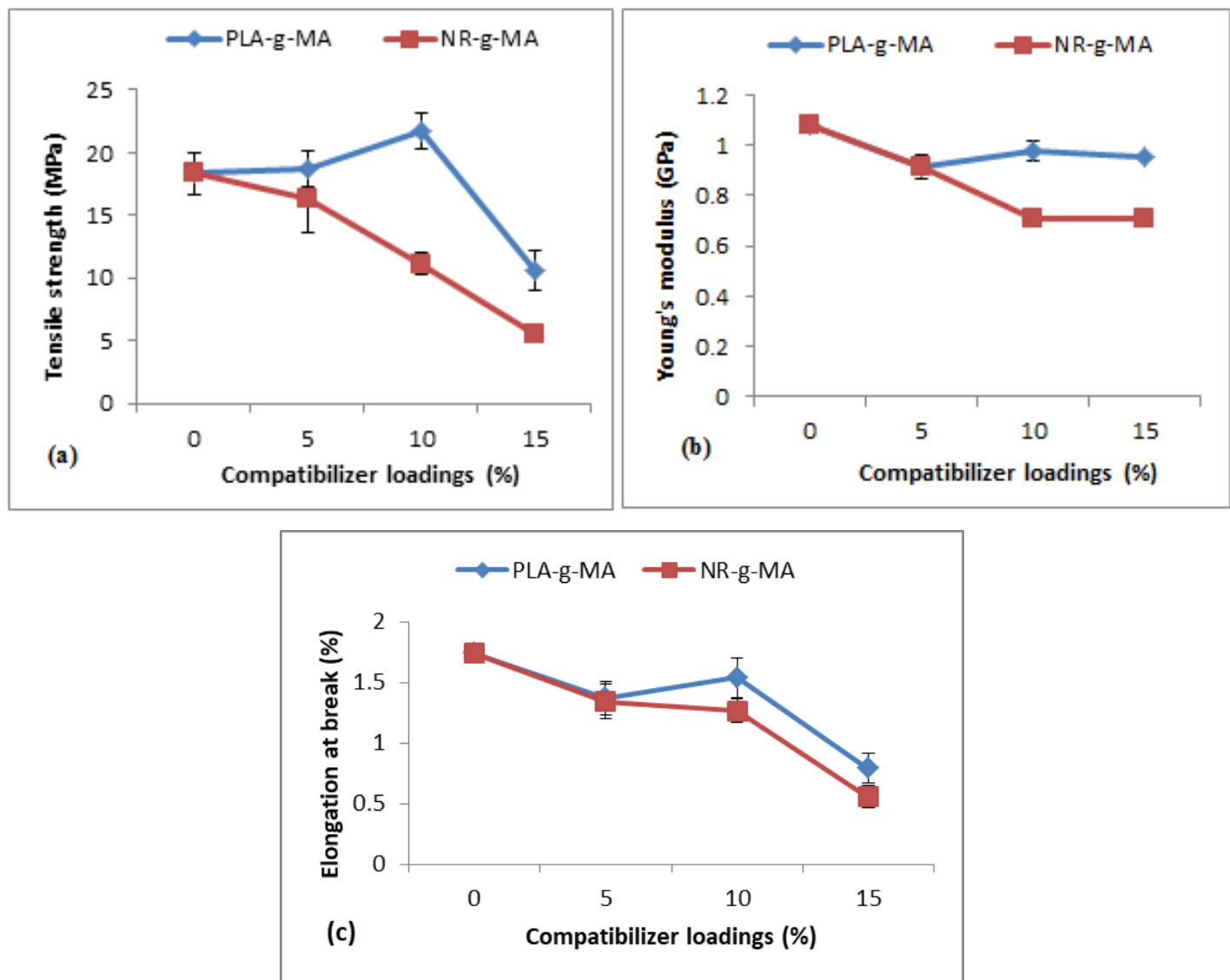

Figure 1. The effect of compatibilizer loadings on (a) tensile strength, (b) Young's modulus and (c) elongation at break of the blends

\section{Thermogravimetric (TGA) Analysis}

Figure 2 shows TGA results of PLA/LNR, PLA/LNR/10\% PLA-g-MA and PLA/LNR/5\% NR-g-MA blends. It can be seen that the TGA curves of the PLA/LNR samples containing compatibilizers delayed the degradation process as compared to that of PLA/LNR without compatibilizer, as shown in inset image over the temperature of 180 - 330 ${ }^{\circ} \mathrm{C}$ where the weight loss of PLA/LNR occurred before the PLA/LNR/compatibilizer samples. At fixed temperature of about $280^{\circ} \mathrm{C}$, PLA/LNR exhibited a greater amount of weight loss than those containing compatibilizer, irrespective of the compatibilizer types. This implies that the thermal stability of the blends incorporated with the compatibilizer was improved. These results are in the agreement with the previous studies [15]. Upon heating to the temperature of $400^{\circ} \mathrm{C}$, the decomposition of PLA/LNR was almost completed with only approximately $0.26 \%$ of residues. The PLA/LNR with compatibilizers, especially NR-g-MA exhibited lesser residues than that of neat PLA/LNR. This was attributed to the greater interaction of the compatibilizer with the matrix, which giving a less carbon residue [15]. 


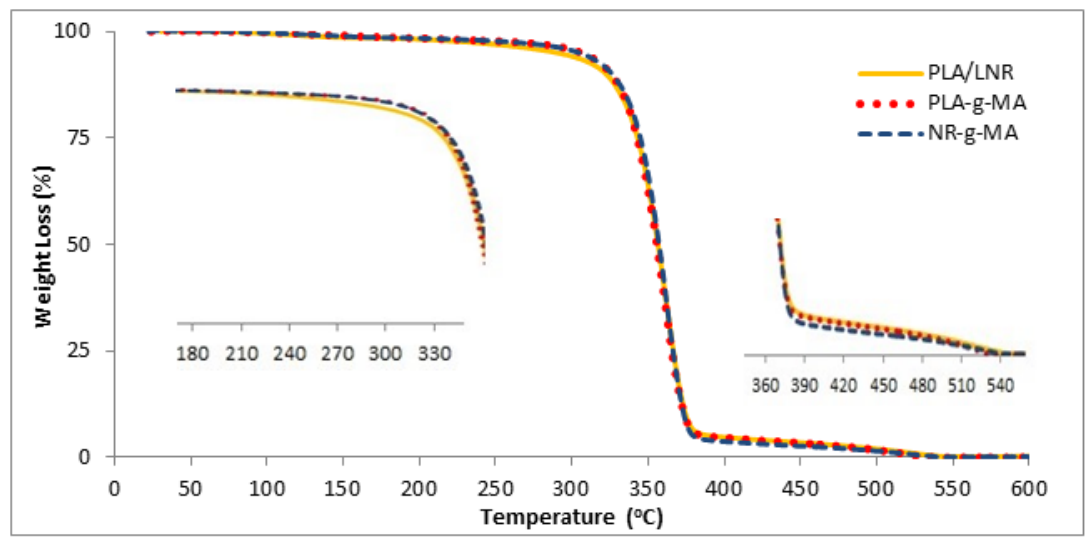

Figure 2. TGA curve of PLA/LNR, PLA/LNR/PLA-g-MA and PLA/LNR/NR-g-MA

\section{Differential scanning calorimetry analysis}

Figure 3 shows the DSC curves of the blends which consist of glass transition temperature $\left(\mathrm{T}_{\mathrm{g}}\right)$, crystallization temperature $\left(T_{c}\right)$ and melting temperature $\left(T_{m}\right)$. The first endothermic peak at around $50-60{ }^{\circ} \mathrm{C}$ indicated $T_{g}, T_{c}$ was at $85^{\circ} \mathrm{C}$ and $\mathrm{T}_{\mathrm{m}}$ took place at around $168{ }^{\circ} \mathrm{C}$. As can be seen from the curves, PLA/LNR blend exhibited $\mathrm{T}_{\mathrm{g}}$ at around $58^{\circ} \mathrm{C}$, whereas the incorporation of compatibilizer into the blends slightly shifted the curve to the right. For the $T_{c}$, it was shown at approximately $85^{\circ} \mathrm{C}$ for PLA/LNR. By incorporating PLA-g-MA, the $T_{c}$ of the blends shifted to the right with a slight increment by approximately $3{ }^{\circ} \mathrm{C}$. However, NR-g-MA showed a similar peak with the PLA/LNR. These changes in PLA-g-MA indicate that the incorporation of compatibilizer increased the thermal stability of the blends. Meanwhile, the $\mathrm{T}_{\mathrm{m}}$ peak showed a tiny right shift for the compatibilized blend. These phenomena imply that a positive effect on the thermal stability has been induced by the incorporation of compatibilizer into the PLA/LNR blend, and higher effectiveness was achieved by PLA-g-MA. This is attributed to which the grafted copolymers may prohibit the crystal formation and delay the $\mathrm{T}_{\mathrm{c}}[6]$.

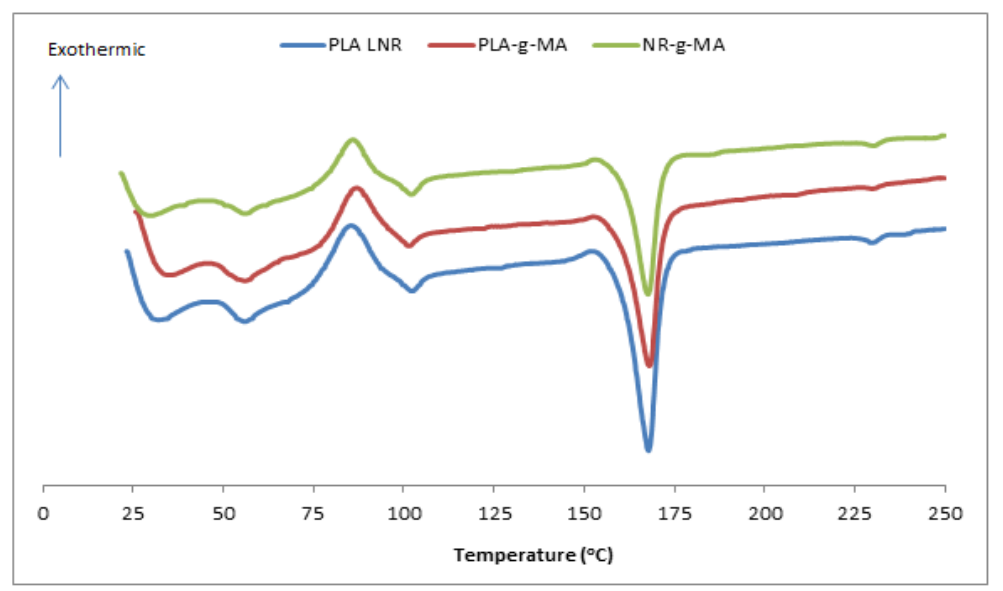

Figure 3. DSC curve of PLA/LNR, PLA/LNR/PLA-g-MA and PLA/LNR/NR-g-MA

\section{Fourier transform infrared analysis}

Figure 4 shows IR-spectra of PLA, PLA/LNR, PLA/LNR/PLA-g-MA and PLA/LNR/NR-g-MA blends. For the neat PLA, the peaks that located at 765, 881, 1096, 1191, 1462 and $1755 \mathrm{~cm}^{-1}$ are assigned to the stretching vibration of $\mathrm{C}=\mathrm{O}$ while the peaks at 2858,2930 and $3316 \mathrm{~cm}^{-1}$ are representing the $\mathrm{CH}_{3}$ stretching of PLA component. PLA exhibited a strong absorption band at $1755 \mathrm{~cm}^{-1}$ which corresponds to the $\mathrm{C}=\mathrm{O}$ stretching of ester 


\section{Mohd Farid Hakim et al: LIQUID NATURAL RUBBER TOUGHENED POLY(LACTIC ACID) BLEND: EFFECTS OF COMPATIBILIZER TYPES AND LOADINGS ON THERMO- MECHANICAL PROPERTIES}

bond. For comparison, the addition of compatibilizer into PLA/LNR exhibits similar spectrum with that of the neat PLA/LNR. By adding the compatibilizer (PLA-g-MA and NR-g-MA) and toughening agent (LNR), a higher intensity of the peak can be observed as compared with PLA itself, exception for the absorption band of 1500-1650 $\mathrm{cm}^{-1}, 2800-3000 \mathrm{~cm}^{-1}, 3316 \mathrm{~cm}^{-1}$. For the blends with PLA-g-MA and NR-g-MA compatibilizer, peak at $1755 \mathrm{~cm}^{-1}$ had a more intense absorption band as compared to neat PLA and this indicates that the reaction was taken place between MA and PLA backbone [14]. Several peaks at 1579, 1645 and $3316 \mathrm{~cm}^{-1}$ which assigned for stretching of PLA were invisible in the spectra of compatibilized blends, and this indicates the chemical reaction occurred between the PLA and grafted MA group. Another small shoulder peak emerged at $1277 \mathrm{~cm}^{-1}$ which corresponds to the $\mathrm{C}=\mathrm{O}$ stretching of carbonyl group of PLA in the PLA-g-MA spectrum. Since the amount of MA used in the blends was relatively small, the $\mathrm{C}=\mathrm{O}$ stretching of MA or anhydride peak was very weak and may overlap with the carbonyl band of PLA [5].

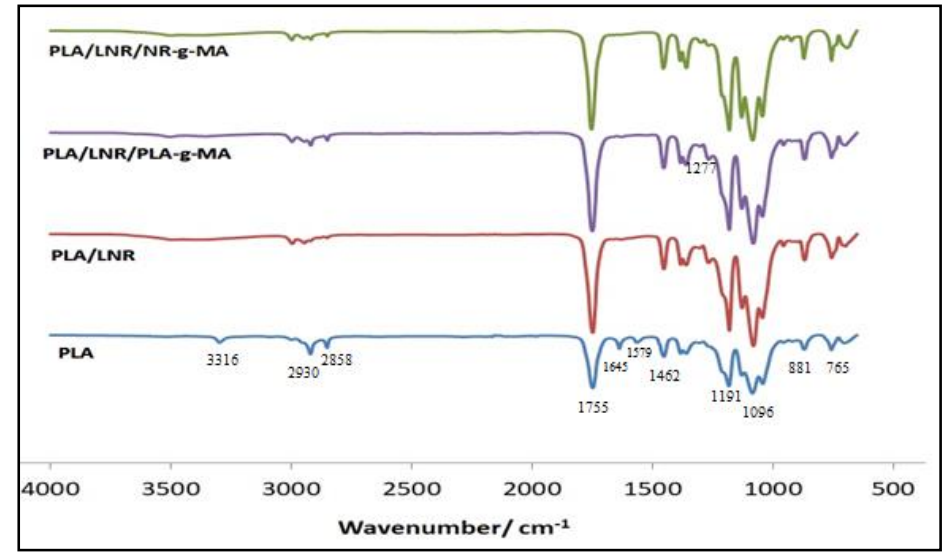

Figure 4. FTIR spectra of PLA, PLA/LNR, PLA/LNR/PLA-g-MA and PLA/LNR/NR-g-MA

\section{Conclusion}

The tensile test showed that the PLA-g-MA was more suitable to be a compatibilizer for PLA/LNR blend as compared to NR-g-MA, and the optimum loading of PLA-g-MA was 10\% PLA-g-MA. The addition of 10\% PLAg-MA into PLA/LNR blend promoted the tensile strength from the PLA/LNR which acted as the control sample. In TGA and DSC, the incorporation of PLA-g-MA into PLA/LNR blends delayed the $T_{g}$ and degradation temperature, hence, the thermal stability of the blend was increased. From FTIR analysis, the difference in the spectra between PLA/LNR and compatibilized PLA/LNR blend showed that MA was successfully grafted to PLA backbone.

\section{Acknowledgement}

The authors gratefully thank the financial support provided by Universiti Kebangsaan Malaysia (UKM) and under grant of DIP-2016-023. We also appreciate the cooperation given by the staff of Materials Science laboratory (FST), and Electron Microscopy Unit, UKM during the SEM viewing.

\section{References}

1. Chen, R. S., Ab Ghani, M. H., Salleh, M. N., Ahmad, S. and Gan, S. (2014). Influence of blend composition and compatibilizer on mecahnical and morphological properties of recycled HDPE/PET blends. Material Sciences and Applications, 5: 943-952.

2. Ahmad, S., Ibrahim, A., Che Som, S., Kohjiya, S. and Yoon, J. R. (1994). Natural rubber-HDPE blends with liquid natural rubber as a compatibilizer: thermal and mechanical properties. Journal of Applied Polymer Science, 51: 1357- 1363.

3. Lee, Y. S., Ahmad, S. Rasid, R., Se Yong, E. N., Yew, C. H. and Tarawneh, M. A. (2011). Effects of liquid natural rubber (LNR) on the mechanical properties of LNR toughened epoxy composite. Sains Malaysiana, 40(7): 679-683. 
4. Tsou, C. H., Hung, W. S., Wu, C. S., Chen, J. C., Huang, C. Y., Chiu, S. H., Tsou, C. Y., Yao, W. H., Lin, S. M., Chu, C. K., Hu, C. C., Lee K. R. and Suen, M. C. (2014). New composition of maleic-anhydride-grafted poly(Lactic Acid)/rice husk with methylenediphenyl diisocyanate. Material Science, 20: 446-451.

5. Orozco, V. H., Brostow, W., Chonkaew, W. and Lopez, B. L. (2009). Preparation and characterization of poly(lactic acid)-g-maleic anhydride + starch blends. Maromol Symposium, 277: 69-80.

6. Mohammad, N. N. B., Arsad, A., Abdullah Sani, N. S. and Basri, M. H. (2017). Effect of compatibilisers on thermal and morphological properties of polylactic acid/natural rubber blends. Chemical Engineering Transactions, 56: 1027- 1032.

7. Ma, P., Jiang, L., Ye, T., Dong, W. and Chen, M. (2014). Melt free-radical grafting of maleic anhydride onto biodegradable poly(lactic acid) by using styrene as a comonomer. Polymers, 6: 1528-1543.

8. Afifi, H. and El-Wakil, A. A. (2008). Study of the effect of natural rubber-graft-maleic anhydride (NR-g-MA) on the compatibility of NR-NBR blends using the ultrasonic technique. Polymer-Plastic Technology and Engineering, 47: 1032-1039.

9. Dong, Z. X., Liu, M. X., Jia, D. M. and Zhou, Y. H. (2013). Synthesis of natural rubber-g-maleic anhydride and its use as a compatibilizer in natural rubber/short nylon fiber composites. Chinese Journal of Polymer Science, 31: 1127-1138.

10. Rui, Z., Hongzhi, L. and Jinwen, Z. (2012). Compatibilizing effects of maleated poly(lactic acid) on properties of PLA/soy protein composites. American Chemical Society, 51(22): 7786-7792.

11. Bijarimi, M., Ahmad, S. and Rasid, R. (2012). Mechanical, thermal and morphological properties of PLA/PP melt blends. International Conference on Agriculture, Chemical And Environmental Sciences: pp. 115-117.

12. Shahdan, D., Ahmad, S. and Flaifel, M. H. (2014). Effect of ultrasonic treatment on tensile properties of PLA/LNR/NiZn ferrite nanocomposite. AIP Conference Proceedings, 1571: 75-82.

13. Abdullah, I. (1992). Liquid natural rubber as a compatibilizer in the blending of natural rubber with polypropylene. Materials Forum, 16: 353-357.

14. Abdullah Sani, N. S., Arsad, A. and Rahmat, A. R. (2014). Synthesis of a compatibilizer and the effects of monomer concentration. Applied Mechanics and Materials, 554: 96-100.

15. Abdullah Sani, N. S., Arsad, A., Rahmat, A. R. and Mohammad N. N. B. (2015). Effects of compatibilizer on thermal and mechanical properties of PLA/NR belnds. Material Science Forum, 819: 241-245.

16. Yi, X., Xu, L., Wang, Y. L., Zhong, G. J., Ji, X. and Li, Z. M. (2010). Morphology and properties of isotactic polypropylene/poly(ethyleneterepthalate) in situ microfibrillar reinforced blends: influence of viscosity ratio. European Polymer Journal, 46: 719-730. 